\title{
The effect of iron on Chilean Alexandrium catenella growth and paralytic shellfish toxin production as related to algal blooms
}

\author{
Kyoko Yarimizu (D) Jorge I. Mardones $(\mathbb{D} \cdot$ Javier Paredes-Mella • \\ Luis Norambuena-Subiabre $\cdot$ Carl J. Carrano $\cdot$ Fumito Maruyama (i)
}

Received: 8 August 2021 / Accepted: 22 October 2021 / Published online: 30 October 2021

(C) The Author(s) 2021

\begin{abstract}
The dinoflagellate Alexandrium catenella is a well-known paralytic shellfish toxin producer that forms harmful algal blooms (HABs) worldwide. Blooms of this species have repeatedly brought severe ecological and economic impacts to Chile, especially in the southern region, where the shellfish and salmon industries are world-famous. The mechanisms of such HABs have been intensively studied but are still unclear. Nutrient overloading is one of the oftendiscussed drivers for HABs. The present study used
\end{abstract}

K. Yarimizu · F. Maruyama ( $₫)$

Microbial Genomics and Ecology, Office of Academic

Research and Industry-Government Collaboration,

Hiroshima University, 1-3-2 Kagamiyama,

Higashi-Hiroshima City, Hiroshima 739-8511, Japan

e-mail: fumito@hiroshima-u.ac.jp

K. Yarimizu

e-mail: kyokoyarimizu@gmail.com

J. I. Mardones $(\bowtie) \cdot$ J. Paredes-Mella .

L. Norambuena-Subiabre

Centro de Estudios de Algas Nocivas (CREAN), Instituto

de Fomento Pesquero (IFOP), Padre Harter 547,

5480000 Puerto Montt, Chile

e-mail: jorge.mardones@ifop.cl

J. Paredes-Mella

e-mail: javier.paredes@ifop.cl

L. Norambuena-Subiabre

e-mail: luis.norambuena@ifop.cl the A. catenella strain isolated from southern Chile to investigate how iron conditions could affect their growth and toxin production as related to HAB. Our results showed that an optimum concentration of iron was pivotal for proper A. catenella growth. Thus, while excess iron exerted a toxic effect, low iron media led to iron insufficiency and growth inhibition. In addition, the study shows that the degree of paralytic shellfish toxin production by A. catenella varied depending on the iron concentration in the

\author{
J. I. Mardones \\ Centro FONDAP de Investigación en Dinámica de \\ Ecosistemas Marinos de Altas Latitudes (IDEAL), \\ Valdivia, Chile \\ C. J. Carrano \\ Department of Chemistry and Biochemistry, San Diego \\ State University, 5500 Campanile Dr., San Diego, \\ CA 92182-1030, USA \\ e-mail: ccarrano@sdsu.edu
}


culture media. The A. catenella strain from southern Chile produced GTX1-4 exclusively in the fmol cell ${ }^{-1}$ scale. Based on these findings, we suggest that including iron and paralytic shellfish toxin measurements in the fields can improve the current HAB monitoring and contribute to an understanding of $A$. catenella bloom dynamics in Chile.

Keywords Trace metal $\cdot$ Iron $\cdot$ Alexandrium catenella $\cdot$ Paralytic shellfish toxin (PST) $\cdot$ Harmful algal bloom (HAB)

\section{Introduction}

Alexandrium catenella is one of the most prominent toxin-producing phytoplankton species and has been increasingly detected on many coasts in the world for decades (Penna et al. 2005; Persich et al. 2006; Anderson et al. 2012). In Chile, A. catenella was first detected in 1972 in the Magallanes region, reached the Aysén region in 1992, and was further expanded to the southern Chiloé Island in the Los Lagos region in 2002 (Guzmán et al. 1975, 2002; Molinet et al. 2003; Varela et al. 2012). Subsequently, A. catenella was detected for the first time on the offshore Pacific coast of Chiloé Island in 2009 and further north along the Pacific coast of the Los Rios region in 2016 (Mardones et al. 2010; Buschmann et al. 2016; Paredes et al. 2019). Due to the paralytic shellfish toxins (PST) that A. catenella produces, blooms of this species in Chile have repeatedly brought severe ecological and economic impacts, especially in the southern region where the shellfish and salmon industries are world-famous (Molinet et al. 2003; Mardones et al. 2010; Varela et al. 2012; Díaz et al. 2019). For instance, the $A$. catenella bloom that occurred in the Aysén region in 2002 caused over 50 human intoxications, three fatalities, and the loss of 1800 metric tons of farmed salmon (Fuentes-Grünewald et al. 2008). The Los Lagos region experienced A. catenella blooms in 2006 and 2009, with damages on the shellfish industry and fish kills equivalent to US\$ 9.2 and 10 million, respectively (Fuentes-Grünewald et al. 2008; Mardones et al. 2010, 2015). The A. catenella bloom in 2016 was particularly severe, affecting $600 \mathrm{~km}$ of benthic artisanal fisheries and over 200 shellfish farms in the Los Lagos region, resulting in economic damage to the coastal communities and igniting social protests that lasted three weeks (Trainer et al. 2020). In 2018, another intense $A$. catenella bloom event reached a world record of 143,130 $\mu \mathrm{g}$ saxitoxin (STX) in $100 \mathrm{~g}$ of shellfish flesh from the Aysén Region, while the regulatory limit is $80 \mu \mathrm{g}$ STX in $100 \mathrm{~g}$ of flesh (Álvarez et al. 2019). It is clear that impacts on the Chilean coastal waters and communities by the blooms of A. catenella have been increasing over the past decade (Paredes et al. 2019, 2020).

Elucidating the mechanisms leading to Harmful Algal Blooms (HABs) has been a challenging task for a long time. Nutrient overload is a frequently discussed topic as a cause of $\mathrm{HAB}$, and those studies revolve around the potential role of macronutrients; nitrogen, phosphorus, and silicate (Hallegraeff 1993; Paredes et al. 2020). In fact, many current algal monitoring programs include nutrient analysis to investigate the effect of these nutrients on bloom dynamics (Hallegraeff and Gollasch 2006). However, iron can also be a growth controlling factor for phytoplankton. Even though iron is one of the most abundant elements on the Earth, it is poorly bioavailable due to its extreme insolubility but remains a crucial nutrient for all living organisms, including phytoplankton (Martin and Fitzwater 1988; Wu and Luther 1994). Under the aerobic and mildly alkaline oceanic conditions, the predominant iron state is largely insoluble Fe(III), with the little soluble Fe(III) mostly complexed with natural organic ligands, which leave negligible bioavailable iron to the surroundings (Rue and Bruland 1995; Martin and Fitzwater 1988; Bruland et al. 1991; Wu and Luther 1994; Sunda 2006). The profound effects of low iron concentrations on phytoplankton growth can be seen in the oceans' so-called High Nutrient Low Chlorophyll (HNLC) regions. The HNLC regions are defined by poor phytoplankton growth despite highly available "major nutrients" but near negligible iron concentrations (Martin and Fitzwater 1988; Martin et al. 1994; Coale et al. 1996; Boyd et al. 2000; Maldonado et al. 2005). Brzezinski et al. (2015) also measured oceanic iron together with other nutrient in California Current, reporting that phytoplankton growth in low-Si: N, high-N: Fe waters responded strongly to added iron, confirming growth limitation by iron. Nevertheless, the relationship between $\mathrm{HAB}$ species and iron has been far less studied than that between HAB species and the "major nutrients" such as nitrogen, 
phosphorus, and silicate. The HAB monitoring that includes iron measurements, as exemplified in Brzezinski et al. (2015), has not been documented in Chile to date. One of the primary reasons for it is that the electrochemical measurement of iron in seawater is a complex and challenging task because of its low concentrations, its existence in two redox states, $\mathrm{Fe}$ (II) and $\mathrm{Fe}(\mathrm{III})$, as well as the potential contamination by ferrous containing apparatus (Croot and Heller 2012).

So far, little information is available on iron concentration in Chilean waters. A study measured iron in transect between the Marquesas Islands to the Chilean coast and reported that total dissolved iron in the Chilean upwelling ranged between 1.2 and $3.9 \mathrm{nM}$ (Blain et al. 2008). This group also reported that onshore water in a southern Chile station $(-34.5471,-72.4047)$ contained $1.2 \mathrm{nM}$ total dissolved iron at 30-m depth. However, iron concentration in other Chilean water regions is unknown, and how iron influences $A$. catenella blooms in Chile is difficult to predict. In general terms, iron concentrations in the oceans are at nanomolar levels (Bruland et al. 1991). Iron typically increases with water depth in vertical columns, as iron in the photic zone is used for primary production (Vraspir and Butler 2009). For example, the offshore Peruvian waters between 9 to 16 ${ }^{\circ} \mathrm{S}$ were reported to contain total dissolved iron of $\sim 2 \mathrm{nM}$ at $1000-\mathrm{m}$ depth and $<1 \mathrm{nM}$ at the surface (Rapp et al. 2019). The open ocean water at 1,000-m depth in the south of Australia contained 0.25 $-0.37 \mathrm{nM}$ total dissolved iron, while that in the upper mixed layer varied between 0.2 and $0.4 \mathrm{nM}$ (Ibisanmi et al. 2011). Regarding the horizontal comparison across the surface ocean water, total dissolved iron depends on location. For example, a group that measured iron at a transect covering the entire western Atlantic Ocean showed that the total dissolved iron in surface water was $<4 \mathrm{nM}$ depending on location (Rijkenberg et al. 2014). From the general information on oceanic iron and phytoplankton stated above, we assumed that iron could influence Chilean $A$. catenella blooms.

To understand the relationship between iron and Chilean A. catenella, the present study investigated the effects of iron on the growth of the A. catenella isolated from southern Chile and its PST production. The iron experiment was designed to observe culture A. catenella growth in different iron concentration media. The study also monitored cultured $A$. catenella growth at varying iron concentration changes. Further, this study was designed to quantitate saxitoxins (STX, dc-STX, neo-STX, NEO), gonyautoxins (GTX1-5, dc GTX2-3), and N-sulfocarbamoyl toxins (C1-2) by $A$. catenella grown in culture containing different iron concentrations. Based on these results, we discussed the potential roles of iron on A. catenella bloom dynamics.

\section{Materials and methods}

Growth media

All plastic and glass containers were soaked in $3 \mathrm{~N}$ hydrochloric acid for two weeks, rinsed with Milli-Q water, and dried in a laminar-flow air bench before use to eliminate any iron contamination (Bruland et al. 1979). Seawater (SW) from Metri (-41.597, - 72.7056, Los Lagos, Chile) was filtered through a $0.22-\mu \mathrm{m}$ pore-sized membrane (MilliporeSigma, WHA7402004), mixed with $0.005 \%$ hydrochloric acid (Trace metal-free $\mathrm{HCl}$, Fisher Scientific, A466250), and autoclaved at $121{ }^{\circ} \mathrm{C}$ for $30 \mathrm{~min}$. The autoclaved SW was maintained at a salinity of 30 and $\mathrm{pH}$ range between 8.0 and 8.2 at ambient temperature. Sterile $\mathrm{L} 1$ nutrient and trace metal mix without $\mathrm{FeCl}_{3} /$ $\mathrm{Na}_{2}$ EDTA were prepared according to Guillard and Hargraves (1993). L1 and L1 without Fe were added to the sterile SW to make a growth media with targeted total iron concentrations from 0 to $10,000 \mathrm{nM}$. It should be noted that the media included all iron phases, and total "dissolved iron" concentrations in the media are much lower than the total iron concentrations $\left([\mathrm{Fe}]_{\mathrm{T}}\right)$. Measuring total dissolved iron concentrations in the media is not possible because equilibrium between the various iron species at $\mathrm{pH}$ 8.2 is reached extremely slowly, resulting in unstable total dissolved iron measurements.

Algal isolation and maintenance

Alexandrium catenella strain CREAN AC11 was isolated from a cyst collected from Quellón (Los Lagos, Chile) and used for all experiments herein. Quellón is one of the most affected areas by $A$. catenella. The process of A. catenella cell isolation was as follow: Sediment samples were collected by scuba divers from Quellón in 2014. The sediment 
samples were transported to the laboratory, where the cysts of $A$. catenella cysts were isolated using the methodology described by Varela et al. (2012). The cysts were then placed in multi-welled cultivation plates with $\mathrm{SW}+\mathrm{L} 1$ medium and exposed to conditions to facilitate germination (i.e., $12{ }^{\circ} \mathrm{C}, 30 \mathrm{psu}$, $35 \mathrm{mmol}$ photons $\mathrm{m}^{-2} \mathrm{~s}^{-1}$, and a photoperiod of 16:8 h light/dark). From each well where cysts germinated, a single cell was transferred to a new well (48-well plate, area of $0.64 \mathrm{~cm}^{2}$ well ${ }^{-1}$ ) using an inverted microscope (Olympus CKX 42) and extended Pasteur pipettes (Andersen and Kawachi 2004). Each well was filled with $500 \mathrm{ml}$ of $\mathrm{SW}+\mathrm{L} 1$ growth media and verified the successful transfer of single cells using an inverted microscope. When the single cell began its division and cell count was increased, cells from each well were transferred into $\mathrm{SW}+\mathrm{L} 1$ in sterile containers (Nunc cell culture treated flasks with filter caps, Fisher Scientific, 12-565-57). Cultures were maintained under $50 \mu \mathrm{mol}$ photons $\mathrm{m}^{-2} \mathrm{~s}^{-1}$ on 16:8 h light: dark cycle at $15 \pm 2{ }^{\circ} \mathrm{C}$ (standard growth condition). The upper portion of a culture containing healthy cells was diluted to $<500$ cells ml $^{-1}$ with new $\mathrm{SW}+\mathrm{L} 1$ media every three weeks. Different strain names were given to different cysts. After screening several strains, the strain CREAN AC11 was used in this study as it was one of the most viable strains.

Growth of A. catenella in controlled iron media

Culture was pretreated with $0.1 \%$ (v/v) antibiotics (penicillin 5units $\mathrm{ml}^{-1}$, streptomycin $5 \mu \mathrm{g} \mathrm{ml}^{-1}$, and neomycin $10 \mu \mathrm{g} \mathrm{ml}^{-1}$ ) (Sigma Aldrich, P4083$100 \mathrm{ml}$ ) for $24 \mathrm{~h}$ under the standard growth condition. This was transferred into $15-\mathrm{ml}$ sterile tubes and centrifuged at $12,750 \mathrm{~m} \mathrm{~s}^{-2}$ for five seconds to collect cell pellets. The supernatant was removed by inversion, and cell pellets were washed three times with $\mathrm{SW}$. Then, cells were re-suspended with $\mathrm{SW}+\mathrm{L} 1$ containing the target total iron concentrations, $[\mathrm{Fe}]_{\mathrm{T}-}$ $=0,10,100,1000$, and 10,000 nM. Cultures were maintained under the standard growth condition and monitored for the cell count using microscopy every 4-6 days for two consecutive subcultures. All data were collected triplicate.
Rescuing iron deficient A. catenella

Alexandrium catenella culture in $\mathrm{SW}+\mathrm{L} 1$ media was aliquoted in two separate containers. One was maintained in $\mathrm{SW}+\mathrm{L} 1$ as a control (containing $[\mathrm{Fe}]_{\mathrm{T}}=10,000 \mathrm{nM}$ ) and subsequently cultured with SW + L1 every three weeks, while the other was subsequently diluted with $\mathrm{SW}+\mathrm{L} 1$ without Fe media every three weeks. Therefore, the first, second, and third subcultures were cell growth comparisons between the control and cultures in $\mathrm{SW}+\mathrm{L} 1$ with $[\mathrm{Fe}]_{\mathrm{T}}=1300 \mathrm{nM}, 468 \mathrm{nM}$, and $100 \mathrm{nM}$, respectively. $[\mathrm{Fe}]_{\mathrm{T}}=5000 \mathrm{nM}$ was added to the third subculture containing $[\mathrm{Fe}]_{\mathrm{T}}=100 \mathrm{nM}$ on day-31, and the growth was monitored for additional 22 days. All data were collected triplicate.

\section{Growth responses}

Growth rates (GR) were determined through a linear regression model $\gamma \mathrm{i}=\alpha+\beta \chi \mathrm{i}$ (Guillard and Hargraves 1993), where $\gamma \mathrm{i}=\ln$-transformed cell density (cells $\mathrm{ml}^{-1}$ ), $\chi \mathrm{i}=$ time (days), $\alpha=$ intercept, and $\beta=$ growth rate (cell division day ${ }^{-1}$ ). Cell density at the end of exponential phase was used as the maximum cell density response (MCD) in cells $\mathrm{ml}^{-1}$.

\section{Statistical analyses}

Analyses of variance (ANOVA) were performed in the linear model framework to evaluate the effect of iron concentration variation (first and second subculture experiments), the effect of iron reduction, or iron addition (rescue experiment) on the GR and MCD responses. A post hoc Tukey HSD analysis was performed to evaluate pairwise growth differences among treatments (levels) of the main effects. In each case, the null statistical hypotheses were rejected at a significance level $(\alpha)$ of 0.01 . Analyses were performed with R software (R Core Team 2020).

\section{Paralytic shellfish toxin assay}

The method from Ravn et al. (1995) was optimized. Alexandrium catenella was grown in $\mathrm{SW}+\mathrm{L} 1$ containing $[\mathrm{Fe}]_{\mathrm{T}}=100,1000$, and 10,000 $\mathrm{nM}$. The condition of $[\mathrm{Fe}]_{\mathrm{T}}=0$ and 10 were not used for toxin assay because A. catenella did not grow under these conditions. On day-7 and day-14, cell counts were 
recorded, and $50 \mathrm{ml}$ of each culture was filtered through GF/F membranes (MilliporeSigma, WHA1825047), which were cut into pieces and soaked in $1.2 \mathrm{ml}$ of diluent (acetic acid $0.05 \mathrm{M}$ ). The samples were vortexed and sonicated for $10 \mathrm{~min}$ followed by filtration through a $0.2 \mu \mathrm{m}$ pore-sized membrane (MilliporeSigma, WHA67771302) to collect filtrate containing toxins. The filtrate was diluted to $1 / 4$ with acetonitrile and analyzed by HilicUHPLC-MS/MS per method by Turner et al. (2019): QQQ Mass Spectrometer (Agilent, G6240A), UHPLC (Agilent, 1290 Infinity) consisting of a quaternary pump G7104A, a high-performance autosampler G7129B, and a column oven G7130A, column (Acquity UHPLC BEH amide column, $100 \times 2.1 \mathrm{~mm}$, $1.7 \mu \mathrm{m}$ particle size), injection volume of $2 \mu \mathrm{L}$, capillary voltage of $3 \mathrm{kV}$ in the negative mode and $3.5 \mathrm{kV}$ in the positive mode, gas flow of $121 \mathrm{~min}^{-1}$ at $350{ }^{\circ} \mathrm{C}$, and nebulizer pressure of 35 psi. The chromatographic conditions and mrm transitions for the different PST analogs were as described in Turner et al. (2019). Certified reference toxins for PST were obtained from the National Research Council of Canada (NRCC, Halifax, Canada). Data processing was done with MassHunter software to provide saxitoxins (STX, dc-STX, neo-STX, NEO), gonyautoxins (GTX1-5, dc GTX2-3), and N-sulfocarbamoyl toxins (C1-2).

\section{Results}

Effect of iron on A. catenella growth

The growth of A. catenella was compared in the $\mathrm{SW}+\mathrm{L} 1$ containing five different $[\mathrm{Fe}]_{\mathrm{T}}(10,000$, $1000,100,10$, and $0 \mathrm{nM}$ ) for the first and second subcultures (Fig. 1). The cells in the media containing $[\mathrm{Fe}]_{\mathrm{T}}=1000 \mathrm{nM}$ grew the greatest in both subcultures, in which the GR for the first and second subculture was 0.137 and 0.120 cell division day ${ }^{-1}$, and the MCD was 10,933 and 4833 cells $\mathrm{ml}^{-1}$, respectively (Table 1). Those in the media containing $[\mathrm{Fe}]_{\mathrm{T}}=10,000 \mathrm{nM}$ showed the second most significant response, in which the GR for the first and second subculture was 0.127 and 0.103 cell division day ${ }^{-1}$, and the MCD was 6567 and 3900 cells $\mathrm{ml}^{-1}$, respectively (ANOVA $\mathrm{p}<0.01$, Table 1 ). On the contrary, the cells in the media containing
$[\mathrm{Fe}]_{\mathrm{T}}=100 \mathrm{nM}$ showed a very slow response in both first and second cultures, in which the GR was 0.084 and 0.069 cell division day ${ }^{-1}$, and the MCD was 3900 and 1000 cells ml $\mathrm{m}^{-1}$, respectively. Those in the media containing $[\mathrm{Fe}]_{\mathrm{T}} \leq 10 \mathrm{nM}$ showed the worst growth in both subcultures (ANOVA p $<0.01$, Table 1).

Rescuing iron-starved A. catenella

In the progressive diminution of total iron concentration experiment, the first, second, and third subculture contained SW + L1 with $[\mathrm{Fe}]_{\mathrm{T}}=1300 \mathrm{nM}, 468 \mathrm{nM}$, and $100 \mathrm{nM}$, respectively. The growth of A. catenella in the media with $[\mathrm{Fe}]_{\mathrm{T}}=1300 \mathrm{nM}$ was comparable to that of control containing L1 level iron concentration $(\fallingdotseq 10,000 \mathrm{nM})$ (Fig. $2 \mathrm{~A})$, in which the GR of $[\mathrm{Fe}]_{\mathrm{T}}=1300 \mathrm{nM}$ culture and that of control in the first, second, and third subculture was $0.088,0.110$, 0.089 , and 0.103 cell division day $^{-1}$, respectively (ANOVA $\mathrm{p}<0.01$, Table 1 ). The cell growth in the second subculture with $[\mathrm{Fe}]_{\mathrm{T}}=468 \mathrm{nM}$ notably slowed down (Fig. 2B), as the GR was 0.045 cell division day $^{-1}$ (ANOVA $\mathrm{p}<0.01$, Table 1 ). By the third subculture where $[\mathrm{Fe}]_{\mathrm{T}}=100 \mathrm{nM}$, A. catenella cells were exposed to the iron-limited condition for three consecutive subcultures (appx. 3 months), the cells struggled to grow, as the GR was 0.069 cell division day ${ }^{-1}$ and MCD was 1000 cells $\mathrm{ml}^{-1}$. Given $[\mathrm{Fe}]_{\mathrm{T}}=5000 \mathrm{nM}$ to this iron-limited culture resulted in the rapid recovery of GR to 0.222 cell division day $^{-1}$ with MCD of 4,733 cells ml ${ }^{-1}$ (Fig. 2C). There was no statistical difference between the control and $[\mathrm{Fe}]_{\mathrm{T}}=5000 \mathrm{nM}$ cultures for MCD (ANOVA $\mathrm{p}>0.01$, Table 1), indicating that the cells had ceased growing under iron deficiency but were rescued by the iron addition.

Iron effect on A. catenella PST production

The A. catenella in SW + L1 with $[\mathrm{Fe}]_{\mathrm{T}}=100,1000$, and 10,000 nM were analyzed on day-7 and day-14 for production of PST, specifically saxitoxins (STX, dcSTX, neo-STX, NEO), gonyautoxins (GTX1-5, dc GTX2-3), and N-sulfocarbamoyl toxins (C1-2). All samples showed the presence of GTX1-4 and the absence of other tested toxins (Table 2). Among gonyautoxins, GTX-3 was the most concentrated toxin in all samples. For example, a cell in the media containing $[\mathrm{Fe}]_{\mathrm{T}}=1000 \mathrm{nM}$ on day-7 contained 9.3, 


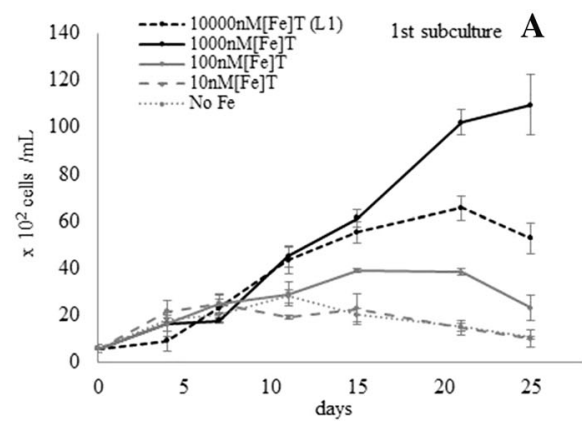

Fig. 1 Alexandrium catenella strain CREAN AC11 in culture media with different total iron concentrations $[\mathrm{Fe}]_{\mathrm{T}}$ : The growth media was SW + L1 with $[\mathrm{Fe}]_{\mathrm{T}}$ of $10,000,1000,1000$, 10, or

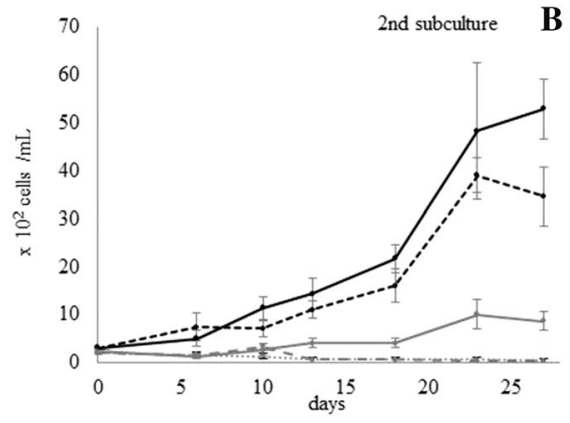

$0 \mathrm{nM}$. The A. catenella in A the first subculture and $\mathbf{B}$ second subculture were grown under the standard growth condition
Table 1 Statistical analysis of $A$. catenella strain CREAN AC11 growth rate in various iron conditions

The list shows Growth rate (GR) in cell division day ${ }^{-1}$, maximum cell density (MCD) in cells $\mathrm{ml}^{-1}$, standard deviation (SD), and results of post hoc Tukey HSD (Tuk) after ANOVA per experiments. $[\mathrm{Fe}]_{\mathrm{T}}$ denotes the total iron concentration in $\mathrm{nM}$ corresponding to the attributes. The GR and MCD were evaluated independently, and each group (divided by the border lines in Table) was evaluated separately. The control was SW + L1 which contained $[\mathrm{Fe}]_{\mathrm{T}}=10,000 \mathrm{nM}$

\begin{tabular}{llllllll}
\hline$[\mathrm{Fe}]_{\mathrm{T}}$ & GR & SD & Tuk. & MCD & SD & Tuk. & Attribute \\
10,000 & 0.127 & 0.007 & $\mathrm{c}$ & 6567 & 513 & $\mathrm{~b}$ & Figure 1A \\
1000 & 0.137 & 0.019 & $\mathrm{c}$ & 10,933 & 1286 & $\mathrm{c}$ & \\
100 & 0.084 & 0.012 & $\mathrm{~b}$ & 3900 & 100 & $\mathrm{a}$ & \\
10 & 0.029 & 0.019 & $\mathrm{a}$ & 2467 & 416 & $\mathrm{a}$ & \\
0 & 0.035 & 0.008 & $\mathrm{a}$ & 2800 & 265 & $\mathrm{a}$ & \\
{$[\mathrm{Fe}]_{\mathrm{T}}$} & GR & SD & Tuk. & $\mathrm{MCD}$ & $\mathrm{SD}$ & Tuk. & Figure 1B \\
10,000 & 0.103 & 0.014 & $\mathrm{~b}$ & 3900 & 361 & $\mathrm{~b}$ & \\
1000 & 0.120 & 0.014 & $\mathrm{~b}$ & 4833 & 1422 & $\mathrm{~b}$ & \\
100 & 0.069 & 0.002 & $\mathrm{~b}$ & 1000 & 300 & $\mathrm{a}$ & \\
10 & -0.170 & 0.011 & $\mathrm{a}$ & 333 & 153 & $\mathrm{a}$ & \\
0 & -0.118 & 0.085 & $\mathrm{a}$ & 133 & 58 & $\mathrm{a}$ & \\
{$[\mathrm{Fe}]_{\mathrm{T}}$} & GR & SD & Tuk. & $\mathrm{MCD}$ & $\mathrm{SD}$ & Tuk. & Figure 2A \\
10,000 (control) & 0.110 & 0.022 & $\mathrm{~b}$ & 2900 & 2900 & $\mathrm{a}$ & \\
1300 & 0.088 & 0.013 & $\mathrm{~b}$ & 1900 & 1900 & $\mathrm{a}$ & \\
10,000 (control) & 0.089 & 0.007 & $\mathrm{~b}$ & 6533 & 6533 & $\mathrm{~b}$ & Figure 2B \\
468 & 0.045 & 0.013 & $\mathrm{a}$ & 2533 & 2533 & $\mathrm{a}$ & \\
{$[\mathrm{Fe}]_{\mathrm{T}}$} & GR & SD & Tuk. & MCD & SD & Tuk. & Figure 2C \\
10,000 (control) & 0.103 & 0.014 & $\mathrm{a}$ & 3900 & 3900 & $\mathrm{~b}$ & \\
100 & 0.069 & 0.002 & $\mathrm{a}$ & 1000 & 1000 & $\mathrm{a}$ & \\
Rescue & 0.222 & 0.041 & $\mathrm{~b}$ & 4733 & 4733 & $\mathrm{~b}$ & \\
\hline & & & & & & & \\
\hline
\end{tabular}

13.9, 50.7, and $15.9 \mathrm{fmol} \mathrm{cell}^{-1}$ of GTX-1, GTX-2, GTX-3, and GTX-4, respectively. The total PST production by an A. catenella cell was pronounced the most at $[\mathrm{Fe}]_{\mathrm{T}}=1000 \mathrm{nM}$ at day-7: On day-7, the total PST was 49.8, 89.8, and $71.8 \mathrm{fmol} \mathrm{cell}^{-1}$ for the condition containing $[\mathrm{Fe}]_{\mathrm{T}}=100,1000$, and $10,000 \mathrm{nM}$, respectively. On day-14, the total PST was $12.9,33.6$, and $10.4 \mathrm{fmol} \mathrm{cell}^{-1}$ for the condition containing $[\mathrm{Fe}]_{\mathrm{T}}=100,1000$, and $10,000 \mathrm{nM}$, respectively.

\section{Discussion}

This study presented evidence that iron was an essential element and growth control nutrient for the Chilean A. catenella strain CREAN AC11. In fact, iron 
Table 2 PST concentration per A. catenella cell

\begin{tabular}{|c|c|c|c|c|c|c|}
\hline Day & {$[\mathrm{Fe}]_{\mathrm{T}}$} & GTX 1 & GTX 2 & GTX 3 & GTX 4 & Total toxin \\
\hline \multirow[t]{3}{*}{7} & $100 \mathrm{nM}$ & $4.1(1.6)$ & $9.3(0.4)$ & $27.8(9.5)$ & $8.6(1.8)$ & 49.8 \\
\hline & $1000 \mathrm{nM}$ & $9.3(1.5)$ & $13.9(0.4)$ & 50.7 (11.6) & $15.9(0.1)$ & 89.8 \\
\hline & $10,000 \mathrm{nM}$ & $7.7(3.5)$ & $10.4(0.1)$ & $41.3(6.7)$ & $12.4(0.3)$ & 71.8 \\
\hline \multirow[t]{3}{*}{14} & $100 \mathrm{nM}$ & $1.2(0.1)$ & $1.9(0.5)$ & $8.4(4.7)$ & $1.4(0.2)$ & 12.9 \\
\hline & $1000 \mathrm{nM}$ & $2.3(1.1)$ & $2.3(0.1)$ & $20.1(2.0)$ & $8.9(2.8)$ & 33.6 \\
\hline & $10,000 \mathrm{nM}$ & $1.3 \pm 0.2$ & $2.1 \pm 0.4$ & $5.5 \pm 1.4$ & $1.6 \pm 0.1$ & 10.4 \\
\hline
\end{tabular}

The A. catenella was grown in the $\mathrm{SW}+\mathrm{L} 1$ containing $[\mathrm{Fe}]_{\mathrm{T}}=100,1000$, and 10,000 $\mathrm{nM}$. At day 7 and 14, 50-ml of each culture was filtered and analyzed for PST. Saxitoxins (STX, dc-STX, neo-STX, NEO), gonyautoxins (GTX5, dc GTX2-3), and $\mathrm{N}$-sulfocarbamoyl toxins (C1-2) were tested but not detected. No peak was detected from diluent. The unit in the table is fmol cell ${ }^{-1}$. Numbers in parentheses are standard deviation in plus/minus $(n=3)$. Total toxin is summation of mean values.

addition rescued poorly growing A. catenella cells suffering from iron deficiency. There was, however, an optimum iron condition for A. catenella, which appeared to be $[\mathrm{Fe}]_{\mathrm{T}}=1000 \mathrm{nM}$. Excess iron exerted a toxic effect, and insufficient iron completely inhibited cell growth for this species. This is consistent with the behavior of most trace elements on biological systems, where nutrient metals have optimal concentrations for a target species, above which growth is limited by intoxication, and below which growth is inhibited by deficiency (Sunda 2006). Therefore, including field iron concentration measurement, likely by anodic stripping voltammetry analysis, to current HAB monitoring programs can be beneficial (Gledhill and van den Berg 1994; Rue and Bruland 1995; van den Berg 1995; Yarimizu et al. 2019). Detection of iron concentration changes in the local marine environment may contribute to early warning of $A$. catenella blooms.

This study demonstrated that the A. catenella cellular toxin production was a fmol cell ${ }^{-1}$ scale and was most pronounced in the media containing $[\mathrm{Fe}]_{\mathrm{T}-}$ $=1000 \mathrm{nM}$, the optimum condition for their growth, at the beginning of the exponential growth phase. This toxin scale is consistent with prior studies, reporting a wide range of toxin content $\left(0.1\right.$ to $\left.450 \mathrm{fmol} \mathrm{cell}^{-1}\right)$ for A. catenella species but all in the fmol scale per cell (Krock et al. 2007; Laabir et al. 2013). Corresponding to our observation, He et al. (2010) performed a similar experiment with Alexandrium tamarense isolated from the sediment in Hong Kong coastal area, reporting that iron availability controlled the growth and toxin production of this species. However, their result was different in which the toxin production by
A. tamarense was most enhanced under iron concentration of 10,000 $\mathrm{nM}$ (He et al. 2010).

The present study further showed that $A$. catenella CREAN AC11 produced GTX 1-4 exclusively. This is consistent with the report by Carbonell et al. (2016) who tested A. catenella obtained from the same region, resulting in exclusive GTX 1-4 production. The toxin production seems to be strain-specific, as many studies reported that Alexandrium species produced different types of PST depending on geographic origin and environmental factors such as salinity (Hamasaki et al. 2001; Grzebyk et al. 2003; Lim and Ogata 2005; Etheridge et al. 2005), temperature (Anderson et al. 1990; Etheridge et al. 2005), light intensity (Hwang and $\mathrm{Lu} \mathrm{2000;}$; Etheridge et al. 2005), and nutrients (Poulton et al. 2005; Xin et al. 2010). The documented PST in southern Chilean A. catenella strains were C1, C2, B1, GTX1, and GTX4 (Krock et al. 2007), C2, GTX3, GTX4, and neoSTX (Varela et al. 2012), and neoSTX, GTX1-5 (Aguilera-Belmonte et al. 2013). Those in the East China Sea, Hong Kong, and France were C1-2 (Li et al. 2011), GTX-1, GTX-3, and GTX4 (Siu et al. 1997; Xu et al. 2012), and C1-C4 plus GTX3-5 (Laabir et al. 2013), respectively. Gaining knowledge of the cellular PST contents and profiles of A. catenella is vital because STX is one of the most potent natural neurotoxins, and a dose of $1 \mathrm{mg}$ of STX is fatal to humans (Wiese et al. 2010). In Chile, STX and its derivatives from A. catenella have caused hundreds of people to suffer from paralytic shellfish poisoning syndromes upon consuming contaminated shellfish (García et al. 2004; Krock et al. 2007). Routine monitoring of STX in coastal waters can provide important implications for strategizing $\mathrm{HAB}$ 

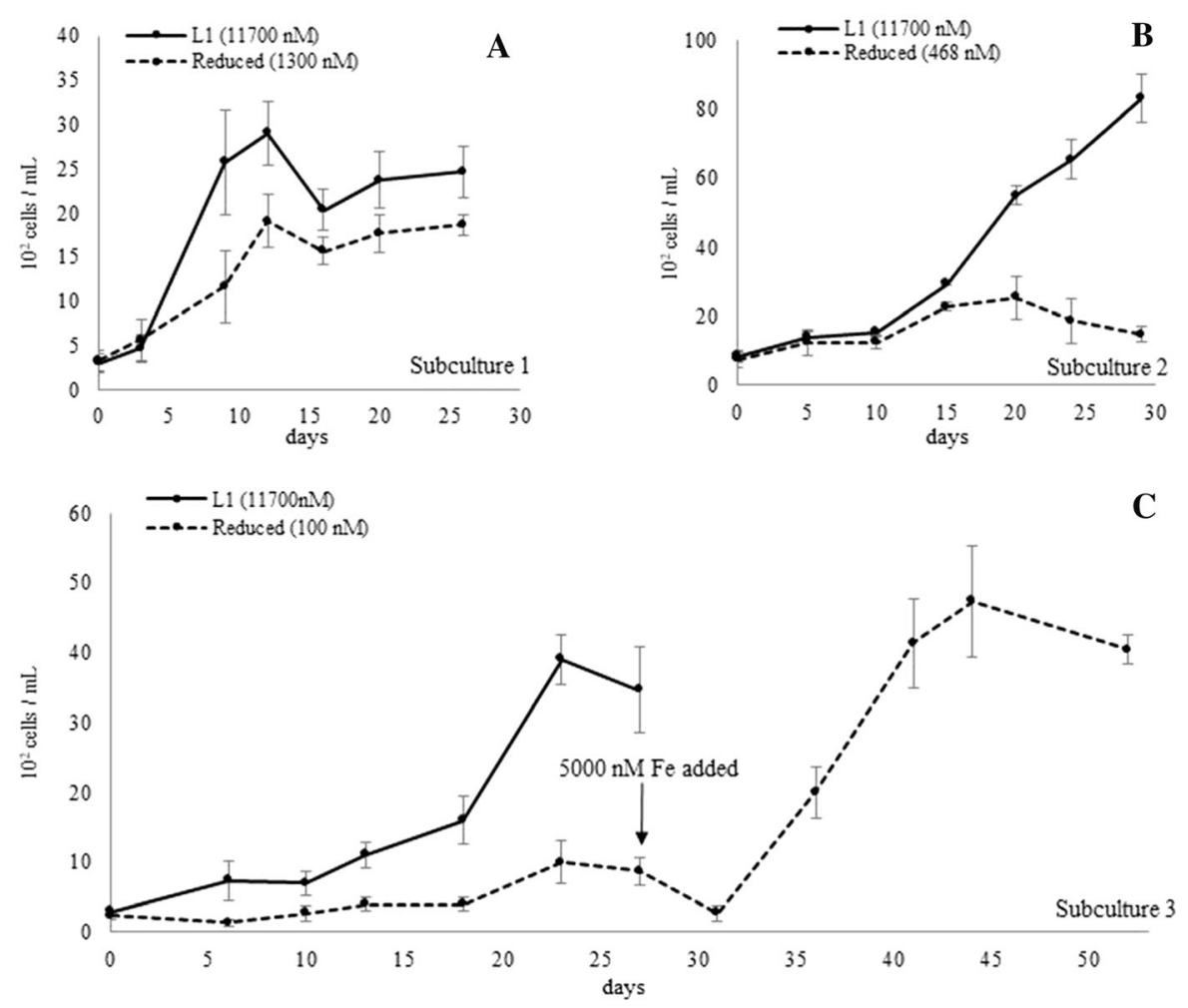

Fig. 2 Growth of A. catenella strain CREAN AC11 in progressive diminution of total iron concentration and iron supplement effect on iron-deficient $A$. catenella: The growth of A. catenella maintained in A the first subculture in $\mathrm{SW}+\mathrm{L} 1$ with $[\mathrm{Fe}]_{\mathrm{T}}=1300 \mathrm{nM}, \mathbf{B}$ second subculture in SW + L1 with

detection, toxicity warning, and PST removal from a contaminated source.

While this laboratory study supported the hypothesis that iron controls Chilean A. catenella growth and toxin production, it is unclear how it operates in the field. It is one of our next assignments to collect iron data from Chilean waters involving both HAB and non-HAB bloom events.

The water in southern Chile has a strong influence from freshwater, glaciers, and coastal runoff in different proportions according to the proximity of the freshwater sources (Sievers and Silva 2008). Freshwater generally contains high iron, and how much river water flows into the sea varies depending on seasons and locations. To best of our knowledge, there is no documented data on iron concentration in either Chilean seawater or freshwater to date. However, other areas typically have $n g \mathrm{l}^{-1}$ for seawater iron and $\mathrm{mg}^{-1}$ for freshwater. For example, the average total
$[\mathrm{Fe}]_{\mathrm{T}}=468 \mathrm{nM}, \mathbf{C}$ third subculture in $\mathrm{SW}+\mathrm{L} 1$ with $[\mathrm{Fe}]_{\mathrm{T}-}$ $=100 \mathrm{nM}$. The control was A. catenella in $\mathrm{SW}+\mathrm{L} 1$ which contained $[\mathrm{Fe}]_{\mathrm{T}}=10,000 \mathrm{nM}$. The A. catenella growth after iron supplement of $[\mathrm{Fe}]_{\mathrm{T}}=5000 \mathrm{nM}$ was given as shown in $(\mathbf{C})$

iron in coastal seawater of Southern California and Baja California was around $5 \mathrm{ng} \mathrm{l}^{-1}$ (Yarimizu et al. 2019). The average total iron in freshwater at Perhonjoki River, Finland, was reported $1.5-3 \mathrm{mg} \mathrm{l}^{-1}$, which was increased to $4-6 \mathrm{mg} \mathrm{l}^{-1}$ after heavy rains and during snowmelt period (Myllynen et al. 1997). Therefore, southern Chilean coast consisted of fjords can be influenced by iron concentration fluctuation depending on nearby freshwater's input. In addition, the open ocean water in the South America is a patch of shallow waters, which can be another factor for the upwelling regime in the region (Hutchins et al. 2002). Those factors could easily alter the local seawater's properties, leading it to interchange the iron redox stages and ratios and creating the regional Fe-limited and Fe-replete areas that potentially influence the $A$. catenella blooms. For the above stated reasons, investigating a correlation between rainfall, seasons, 
and iron concentration may provide information to characterize the local HABs.

In the meantime, the possibility of anthropogenic factors as drivers of A. catenella blooms in southern Chile cannot be eliminated. The salmon industry in southern Chile has rapidly expanded the scale of businesses since the 1980s to its current production of nearly 800,000 tons per year (Mascareño et al. 2018; Armijo et al. 2020). It is a constant concern for the locals that the nutrient overloading to the coastal waters to feed salmon could change the ecosystem. For the HAB events in 2016 in Chile, a precursor bloom of Pseudochattonella verruculosa killed tons of salmon in northern Chiloé Island first, and the dead salmon were dumped off the Islands' coast with the government's permission. The notorious A. catenella bloom occurred in the region soon after (Mascareño et al. 2018; Armijo et al. 2020). The Chilean government claimed that El Nino was the cause of this A. catenella bloom (Buschmann et al. 2016; Armijo et al. 2020; Trainer et al. 2020). However, a debate between the government and locals is ongoing whether the cause was anthropogenic eutrophication. Salmon is an ironrich food source $(0.8 \mathrm{mg}$ iron per $100 \mathrm{~g}$ flesh of wild Atlantic raw salmon, USDA FDC ID 173086, NDB 15076). Theoretically, throwing 4700 tons of dead salmon could inject massive iron into the local ocean, which could leave speculation that this action may have influenced phytoplankton biomass increase, as exemplified in the open-ocean iron enrichment experiment (IronEX I) by Martin et al. (1994).

Lastly, it should be outlined that this study focused on a southern Chilean A. catenella strain. The obtained toxin profile and response to iron concentration can be different for the strains from other regions. For instance, Paredes et al. (2020) evidenced that the growth responses of A. catenella clones isolated along Chilean fjords have different reaction norms under different drivers. It is one of the reasons that each HAB is unique and unpredictable.

\section{Conclusion}

This study demonstrated that iron is a growth-limiting and -stimulating factor for the Chilean A. catenella strain CREAN AC11. The study also revealed that the toxins detected from this strain were GTX1-4 in fmol scale per cell, and its production was increased with the optimum iron concentration in media. Accounting for these findings, we suggest that the Chilean HAB monitoring may improve if the measurement of iron concentration and saxitoxin in water samples are included. The information can help understand the environmental drivers for the A. catenella bloom dynamics, with the concomitant mitigation on socioecological and economic issues related to the HABs.

Author contributions All authors reviewed and approved the final manuscript. Each took the following responsibilities: KY, JIM, and JPM performed building the strategy, experiments, data interpretation, and manuscript writing. JPM isolated and maintained the A. catenella strain and performed the GR statistical analysis. LNS performed the toxin analysis and the part of manuscript writing. CJC provided advice on iron chemistry and edited the final manuscript. FM supervised the overall project.

Funding This study was supported by the Grant (JPMJSA1705) for a study on Science and Technology Research Partnership for Sustainable Development Monitoring Algae in Chile (SATREPS-MACH).

\section{Declarations}

Conflict of interest We do not have financial interests or personal relationships that could have influenced the work reported in this paper.

Open Access This article is licensed under a Creative Commons Attribution 4.0 International License, which permits use, sharing, adaptation, distribution and reproduction in any medium or format, as long as you give appropriate credit to the original author(s) and the source, provide a link to the Creative Commons licence, and indicate if changes were made. The images or other third party material in this article are included in the article's Creative Commons licence, unless indicated otherwise in a credit line to the material. If material is not included in the article's Creative Commons licence and your intended use is not permitted by statutory regulation or exceeds the permitted use, you will need to obtain permission directly from the copyright holder. To view a copy of this licence, visit http://creativecommons.org/licenses/by/4.0/.

\section{Appendix}

See Table 3. 
Table 3 List of materials and reagents used to prepare nutrient for media preparation

\begin{tabular}{lll}
\hline Manufacture & Item & Part number \\
\hline Sigma-Aldrich & Iron(III) chloride hexahydrate & $10025-77-1$ \\
& Manganese(II) chloride tetrahydrate & $13446-34-9$ \\
& Hexadecyltrimethylammonium bromide & H6269-100G \\
& Zinc sulfate heptahydrate & 1088830500 \\
& Cobalt(II) chloride hexahydrate & 8025400010 \\
& Copper(II) sulfate pentahydrate & $209198-5 \mathrm{G}$ \\
& Sodium molybdate dehydrate & $331058-5 \mathrm{G}$ \\
& Selenous acid & $211176-10 \mathrm{G}$ \\
& Nickel(II) sulfate hexahydrate & $227676-100 \mathrm{G}$ \\
& Sodium orthovanadate & $450243-10 \mathrm{G}$ \\
& Potassium chromate & $216615-100 \mathrm{G}$ \\
Ethylenediaminetetraaceticacid, tetrasodium salt dihydrate & BP121-500
\end{tabular}

\section{References}

Aguilera-Belmonte A, Inostroza I, Carrillo KS, Franco JM, Riobó P, Gómez PI (2013) The combined effect of salinity and temperature on the growth and toxin content of four Chilean strains of Alexandrium catenella (Whedon and Kofoid) Balech 1985 (Dinophyceae) isolated from an outbreak occurring in southern Chile in 2009. Harmful Algae 23:55-59. https://doi.org/10.1016/j.hal.2012.12.006

Álvarez G, Díaz PA, Godoy M, Araya M, Ganuza I, Pino R, Álvarez F, Rengel J, Hernández C, Uribe E, Blanco J (2019) Paralytic shellfish toxins in surf clams Mesodesma donacium during a large bloom of Alexandrium catenella dinoflagellates associated to an intense shellfish mass mortality. Toxins (basel). https://doi.org/10.3390/ toxins11040188

Andersen RA, Kawachi M (2004) Traditional microalgae isolation techniques. In: Andersen RA (ed) Algal culturing techniques, 1st edn. Academic Press, Cambridge, MA, USA, pp 83-100

Anderson DM, Kulis DM, Sullivan JJ, Hall S, Lee C (1990) Dynamics and physiology of saxitoxin production by the dinoflagellates Alexandrium spp. Mar Biol 104(3):511-524. https://doi.org/10.1007/BF01314358

Anderson DM, Cembella AD, Hallegraeff GM (2012) Progress in understanding harmful algal blooms: paradigm shifts and new technologies for research, monitoring, and management. Annu Rev Mar Sci 4:143-176. https://doi.org/10. 1146/annurev-marine-120308-081121

Armijo J, Oerder V, Auger PA, Bravo A, Molina E (2020) The 2016 red tide crisis in southern Chile: possible influence of the mass oceanic dumping of dead salmons. Mar Pollut Bull 150:110603. https://doi.org/10.1016/j.marpolbul. 2019.110603

Blain S, Bonnet S, Guieu C (2008) Dissolved iron distribution in the tropical and sub tropical South Eastern Pacific. Biogeosciences 5(1):269-280. https://doi.org/10.5194/bg-5269-2008

Boyd PW, Watson AJ, Law CS, Abraham ER, Trull T, Murdoch $\mathrm{R}$, Bakker DCE, Bowie AR, Buesseler KO, Chang H, Charette M, Croot P, Downing K, Frew R, Gall M, Hadfield
M, Hall J, Harvey M, Jameson G, LaRoche J, Liddicoat M, Ling R, Maldonado MT, McKay RM, Nodder S, Pickmere S, Pridmore R, Rintoul S, Safi K, Sutton P, Strzepek R, Tanneberger K, Turner S, Waite A, Zeldis J (2000) A mesoscale phytoplankton bloom in the polar Southern Ocean stimulated by iron fertilization. Nature 407(6805):695-702. https://doi.org/10.1038/35037500

Bruland KW, Franks RP, Knauer GA, Martin JH (1979) Sampling and analytical methods for the determination of copper, cadmium, zinc, and nickel at the nanogram per liter level in sea water. Anal Chim Acta 105:233-245. https:// doi.org/10.1016/S0003-2670(01)83754-5

Bruland KW, Donat JR, Hutchins DA (1991) Interactive influences of bioactive trace metals on biological production in oceanic waters. Limnol Oceanogr 36(8):1555-1577. https://doi.org/10.4319/lo.1991.36.8.1555

Brzezinski MA, Krause JW, Bundy RM, Barbeau KA, Franks P, Goericke R, Landry MR, Stukel MR (2015) Enhanced silica ballasting from iron stress sustains carbon export in a frontal zone within the California current. J Geophys Res 120:4654-4668. https://doi.org/10.1002/2015JC010829

Buschmann A, Farías L, Tapia F, Varela D, Vásquez M (2016) Informe Final: Comisión Marea Roja (CMR). Alphen aan den Rijn: Wolters Kluwer.

Carbonell P, Martínes R, Espinoza-Gonzáles O, Guzmán L (2016). Feeding behavior of two species of copepods exposed to dinoflagellate Alexandrium catenella in single and mixed diets. Poster presented at the ICHA 2016, Florianopolis, Brazil.

Coale KH, Johnson KS, Fitzwater SE, Gordon RM, Tanner S, Chavez FP, Ferioli L, Sakamoto C, Rogers P, Millero F, Steinberg P, Nightingale P, Cooper D, Cochlan WP, Landry MR, Constantinou J, Rollwagen G, Trasvina A, Kudela R (1996) A massive phytoplankton bloom induced by an ecosystem-scale iron fertilization experiment in the equatorial Pacific Ocean. Nature 383(6600):495-501. https://doi.org/10.1038/383495a0

Croot PL, Heller MI (2012) The importance of kinetics and redox in the biogeochemical cycling of iron in the surface ocean. Front Microbiol 3(219):1-15. https://doi.org/10. 3389/fmicb.2012.00219 
Díaz P, Alvarez G, Varela D, Santos IE, Diaz M, Molinet C, Seguel M, Aguilera BA, Guzmán L, Uribe E, Rengel J, Hernández C, Segura C, Figueroa R (2019) Impacts of harmful algal blooms on the aquaculture industry: Chile as a case study. Perspect Phycol 6(1-2):39-50. https://doi. org/10.1127/pip/2019/0081

Etheridge SM, Roesler CS (2005) Effects of temperature, irradiance, and salinity on photosynthesis, growth rates, total toxicity, and toxin composition for Alexandrium fundyense isolates from the Gulf of Maine and Bay of Fundy. Deep Sea Res Part II 52(19):2491-2500. https://doi.org/10.1016/ j.dsr2.2005.06.026

Fuentes-Grünewald C, Clement A, Aguilera BA (2008) Alexandrium catenella bloom and the impact on fish farming in the XI region, Chile. Paper presented at the Books of proceedings of 12th International Conference on Harmful Algae, Copenhagen, pp. 183-186

García C, del Carmen BM, Lagos M, Lagos N (2004) Paralytic shellfish poisoning: post-mortem analysis of tissue and body fluid samples from human victims in the Patagonia fjords. Toxicon 43(2):149-158. https://doi.org/10.1016/j. toxicon.2003.11.018

Gledhill M, van den Berg CMG (1994) Determination of complexation of iron(III) with natural organic complexing ligands in seawater using cathodic stripping voltammetry. Mar Chem 47(1):41-54. https://doi.org/10.1016/03044203(84)90035-5

Grzebyk D, Béchemin C, Ward CJ, Vérité C, Codd GA, Maestrini SY (2003) Effects of salinity and two coastal waters on the growth and toxin content of the dinoflagellate Alexandrium minutum. J Plankton Res 25(10):1185-1199. https://doi.org/10.1093/plankt/fbg088

Guillard RRL, Hargraves PE (1993) Stichochrysis immobilis is a diatom, not a chrysophyte. Phycologia 32(3):234-236. https://doi.org/10.2216/i0031-8884-32-3-234.1

Guzmán ML, Campodónico GI, Antunovic M (1975) Estudios sobre un florecimiento tóxico causado por Gonyaulax catenella en Magallanes. III. Fitoplancton asociado. Anales del Instituto de la Patagonia V1 (No.1-2):209-223.

Guzmán L, Pacheco H, Pizarro G, Alarcón C (2002) Alexandrium catenella y veneno paralizante de los mariscos en Chile. In: Sar EA, Ferrario ME, Reguera B (eds) Floraciones Algales Nocivas en el Cono Sur Americano, 1st edn. Instituto Español de Oceanografía, Madrid, Spain, pp 235-256

Hallegraeff GM (1993) A review of harmful algal blooms and their apparent global increase. Phycologia 32(2):79-99. https://doi.org/10.2216/i0031-8884-32-2-79.1

Hallegraeff G, Gollasch S (2006) Ecological studies: ecology of harmful algae. In: Caldwell LMM, Heldmaier MG, Jackson DRB, Lange WOL, Mooney SHA, Schulze JED, Sommer KU (eds) Anthropogenic introductions of microalgae. Springer, Netherlands, pp 379-402

Hamasaki K, Horie M, Tokimitsu S, Toda T, Taguchi S (2001) Variability in toxicity of the Dinoflagellate Alexandrium tamarense isolated from Hiroshima Bay, Western Japan, as a reflection of changing environmental conditions. J Plankton Res 23(3):271-278. https://doi.org/10.1093/ plankt/23.3.271

He H, Chen F, Li H, Xiang W, Li Y, Jiang Y (2010) Effect of iron on growth, biochemical composition and paralytic shellfish poisoning toxins production of Alexandrium tamarense. Harmful Algae 9(1):98-104. https://doi.org/10. 1016/j.hal.2009.08.006

Hutchins D, Hare C, Weaver R, Zhang Y, Firme G, DiTullio G, Alm M, Riseman S, Maucher J, Geesey M (2002) Phytoplankton iron limitation in the Humboldt current and Peru upwelling. Limnol Oceanogr 47:997-1011. https://doi.org/ 10.4319/lo.2002.47.4.0997

Hwang DF, Lu YH (2000) Influence of environmental and nutritional factors on growth, toxicity, and toxin profile of dinoflagellate Alexandrium minutum. Toxicon 38(11):1491-1503. https://doi.org/10.1016/s00410101(00)00080-5

Ibisanmi E, Sander SG, Boyd PW, Bowie AR, Hunter KA (2011) Vertical distributions of iron-(III) complexin gligands in the Southern Ocean. Deep Sea Res II 58:2113-2125. https://doi.org/10.1016/j.dsr2.2011.05.028

Krock B, Seguel CG, Cembella AD (2007) Toxin profile of Alexandrium catenella from the Chilean coast as determined by liquid chromatography with fluorescence detection and liquid chromatography coupled with tandem mass spectrometry. Harmful Algae 6(5):734-744. https://doi. org/10.1016/j.hal.2007.02.005

Laabir M, Collos Y, Masseret E, Grzebyk D, Abadie E, Savart V, Sibat M, Amzil Z (2013) Influence of environmental factors on the paralytic shellfish toxin content and profile of Alexandrium catenella (Dinophyceae) isolated from the Mediterranean Sea. Mar Drugs 11(5):1583-1601. https:// doi.org/10.3390/md11051583

Li TS, Yu RC, Zhou MJ (2011) Short-term effects of different nitrogen substrates on growth and toxin production of dinoflagellate Alexandrium catenella Balech (strain ACDH). Harmful Algae 12:46-54. https://doi.org/10.1016/ j.hal.2011.08.011

Lim PT, Ogata T (2005) Salinity effect on growth and toxin production of four tropical Alexandrium species (Dinophyceae). Toxicon 45(6):699-710. https://doi.org/10.1016/ j.toxicon.2005.01.007

Maldonado MT, Strzepek RF, Sander S, Boyd PW (2005) Acquisition of iron bound to strong organic complexes, with different $\mathrm{Fe}$ binding groups and photochemical reactivities by plankton communities in Fe-limited subantarctic waters. Global Biogeochem Cycles. https://doi.org/10. 1029/2005GB002481

Mardones J, Clement A, Rojas X, Aparicio C (2010) Alexandrium catenella during 2009 in Chilean waters, and recent expansion to coastal ocean. Harmful Algae News 41:8-9

Mardones JI, Dorantes-Aranda JJ, Nichols PD, Hallegraeff GM (2015) Fish gill damage by the dinoflagellate Alexandrium catenella from Chilean fjords: synergistic action of ROS and PUFA. Harmful Algae 49:40-49. https://doi.org/10. 1016/j.hal.2015.09.001

Martin JH, Fitzwater SE (1988) Iron deficiency limits phytoplankton growth in the north-east Pacific subarctic. Nature 331(6154):341-343. https://doi.org/10.1038/331341a0

Martin JH, Coale KH, Johnson KS, Fitzwater SE, Gordon RM, Tanner SJ, Hunter CN, Elrod VA, Nowicki JL, Coley TL, Barber RT, Lindley S, Watson AJ, Van Scoy K, Law CS, Liddicoat MI, Ling R, Stanton T, Stockel J, Collins C, Anderson A, Bidigare R, Ondrusek M, Latasa M, Millero FJ, Lee K, Yao W, Zhang JZ, Friederich G, Sakamoto C, 
Chavez F, Buck K, Kolber Z, Greene R, Falkowski P, Chisholm SW, Hoge F, Swift R, Yungel J, Turner S, Nightingale P, Hatton A, Liss P, Tindale NW (1994) Testing the iron hypothesis in ecosystems of the equatorial Pacific Ocean. Nature 371(6493):123-129. https://doi.org/ 10.1038/371123a0

Mascareño A, Cordero R, Azócar G, Billi M, Henríquez PA, Ruz G (2018) Controversies in social-ecological systems: lessons from a major red tide crisis on Chiloe Island, Chile. Ecol Soc. https://doi.org/10.5751/ES-10300-230415

Molinet C, Lafon A, Lembeye G, Moreno C (2003) Spatial and temporal distribution patterns of blooms of Alexandrium catenella (Whedon and Kofoid) Balech 1985, on inland seas of northwest Patagonia, Chile. Rev Chil Hist Nat 76:681-698

Myllynen K, Ojutkangas E, Nikinmaa M (1997) River water with high iron concentration and low $\mathrm{pH}$ causes mortality of lamprey roe and newly hatched larvae. Ecotoxicol Environ Safety 36(1):43-48. https://doi.org/10.1006/eesa. 1996.1484

Paredes J, Varela D, Martínez C, Zúñiga A, Correa K, Villarroel A, Olivares B (2019) Population genetic structure at the northern edge of the distribution of Alexandrium catenella in the Patagonian fjords and its expansion along the open Pacific Ocean coast. Front Marine Sci. https://doi.org/10. 3389/fmars.2018.00532

Paredes-Mella J, Varela D, Fernández P, Espinoza-González O (2020) Growth performance of Alexandrium catenella from the Chilean fjords under different environmental drivers: plasticity as a response to a highly variable environment. J Plankton Res 42(2):119-134. https://doi.org/10. 1093/plankt/fbaa011

Penna A, Garcés E, Vila M, Giacobbe MG, Fraga S, Lugliè A, Bravo I, Bertozzini E, Vernesi C (2005) Alexandrium catenella (Dinophyceae), a toxic ribotype expanding in the NW Mediterranean Sea. Mar Biol 148(1):13-23. https:// doi.org/10.1007/s00227-005-0067-5

Persich GR, Kulis DM, Lilly EL, Anderson DM, Garcia VMT (2006) Probable origin and toxin profile of Alexandrium tamarense (Lebour) Balech from southern Brazil. Harmful Algae 5(1):36-44. https://doi.org/10.1016/j.hal.2005.04. 002

Poulton NJ, Keafer BA, Anderson DM (2005) Toxin variability in natural populations of Alexandrium fundyense in Casco Bay, Maine evidence of nitrogen limitation. Deep Sea Res Part II 52(19):2501-2521. https://doi.org/10.1016/j.dsr2. 2005.06.029

R Core Team (2020) R: A language and environment for statistical computing. R Foundation for Statistical Computing, Vienna, Austria. https://www.R-project.org/

Rapp I, Schlosser C, Browning TJ, Wolf F, Le Moigne FAC, Gledhill M, Achterberg EP (2020) El Niño-driven oxygenation impacts Peruvian shelf iron supply to the South Pacific Ocean. Geophys Res Lett. https://doi.org/10.1029/ 2019GL086631

Ravn H, Anthoni U, Christophersen C, Nielsen PH, Oshima Y (1995) Standardized extraction method for paralytic shellfish toxins in phytoplankton. J Appl Phycol 7(6):589-594. https://doi.org/10.1007/BF00003947

Rijkenberg MJA, Middag R, Laan P, Gerringa LJA, van Aken HM, Schoemann V, de Baar HJW (2014) The distribution of dissolved iron in the West Atlantic Ocean. PLoS ONE 9(6):e101323. https://doi.org/10.1371/journal.pone. 0101323

Rue EL, Bruland KW (1995) Complexation of iron(III) by natural organic ligands in the Central North Pacific as determined by a new competitive ligand equilibration/adsorptive cathodic stripping voltammetric method. Mar Chem 50(1):117-138. https://doi.org/10.1016/03044203(95)00031-L

Sievers HA, Silva N (2008) Water masses and circulation in austral Chilean channels and fjords. In: Silva N, González SP (eds) Progress in the oceanographic knowledge of Chilean interior waters, from Puerto Montt to Cape Horn. Comité Oceanográfico Nacional, Pontificia Universidad Católica de Valparaíso, Valparaiso, pp 53-58

Siu, GKY, Young MLC, Chan DKO (1997) Environmental and nutritional factors which regulate population dynamics and toxin production in the dinoflagellate Alexandrium catenella. Paper presented at the Asia-Pacific Conference on Science and Management of Coastal Environment, Dordrecht.

Sunda WG (2006) Trace metals and harmful algal blooms. In: Caldwell LMM, Heldmaier MG, Jackson DRB, Lange WOL, Mooney SHA, Schulze JED, Sommer KU (eds) Anthropogenic introductions of microalgae. Springer, Netherlands, pp 203-214

Trainer VL, Moore SK, Hallegraeff G, Kudela RM, Clement A, Mardones JI, Cochlan WP (2020) Pelagic harmful algal blooms and climate change: lessons from nature's experiments with extremes. Harmful Algae 91:101591. https:// doi.org/10.1016/j.hal.2019.03.009

Turner AD, Dhanji-Rapkova M, Fong SYT, Hungerford J, McNabb PS, Boundy MJ, Harwood DT (2019) Ultrahighperformance hydrophilic interaction liquid chromatography with tandem mass spectrometry method for the determination of paralytic shellfish toxins and tetrodotoxin in mussels, oysters, clams, cockles, and scallops: collaborative study. J AOAC Int. https://doi.org/10.5740/jaoacint. 19-0240

van den Berg CMG (1995) Evidence for organic complexation of iron in seawater. Mar Chem 50(1):139-157. https://doi. org/10.1016/0304-4203(95)00032-M

Varela D, Paredes J, Alves-de-Souza C, Seguel M, Sfeir A, Frangópulos M (2012) Intraregional variation among Alexandrium catenella (Dinophyceae) strains from southern Chile: morphological, toxicological and genetic diversity. Harmful Algae 15:8-18. https://doi.org/10.1016/ j.hal.2011.10.029

Vraspir JM, Butler A (2009) Chemistry of marine ligands and siderophores. Ann Rev Mar Sci 1(1):43-63. https://doi.org/ 10.1146/annurev.marine.010908.163712

Wiese M, D'Agostino PM, Mihali TK, Moffitt MC, Neilan BA (2010) Neurotoxic alkaloids: saxitoxin and its analogs. Mar Drugs 8(7):2185-2211. https://doi.org/10.3390/ md8072185

Wu J, Luther GW III (1994) Size-fractionated iron concentrations in the water column of the western North Atlantic Ocean. Limnol Oceanogr 39(5):1119-1129. https://doi. org/10.4319/lo.1994.39.5.1119

Xin L, Hu HY, Ke G, Sun YX (2010) Effects of different nitrogen and phosphorus concentrations on the growth, 
nutrient uptake, and lipid accumulation of a freshwater microalga Scenedesmus sp. Bioresour Technol 101(14):5494-5500. https://doi.org/10.1016/j.biortech. 2010.02.016

Xu J, Ho AYT, He L, Yin K, Hung C, Choi N, Lam PKS, Wu RSS, Anderson DM, Harrison PJ (2012) Effects of inorganic and organic nitrogen and phosphorus on the growth and toxicity of two Alexandrium species from Hong Kong. Harmful Algae 16:89-97. https://doi.org/10.1016/j.hal. 2012.02.006
Yarimizu K, Cruz-Lopez R, Garcia-Mendoza E, Edwards M, Carter ML, Carrano CJ (2019) Distribution of dissolved iron and bacteria producing the photoactive siderophore, vibrioferrin, in waters off Southern California and Northern Baja. Biometals 32:139-154. https://doi.org/10.1007/ s10534-018-00163-3

Publisher's Note Springer Nature remains neutral with regard to jurisdictional claims in published maps and institutional affiliations. 